\title{
Unsealed Device Packaging
}

National Cancer Institute

\section{Source}

National Cancer Institute. Unsealed Device Packaging. NCI Thesaurus. Code C62810.

Problem associated with the device's loss of packaging seal. 